\title{
Use of a Climatic Rule and Fuzzy Sets to Model Geographic Distribution of Climatic Risk for European Canker (Neonectria galligena) of Apple
}

\author{
Kwang Soo Kim and Robert M. Beresford
}

First author: Department of Plant Science and Research Institute for Agriculture and Life Sciences, Seoul National University, Seoul, 151-921, Korea; and second author: Mount Albert Research Centre, The New Zealand Institute for Plant \& Food Research Ltd., Private bag 92 169, Mt. Albert, Auckland, New Zealand.

Accepted for publication 21 July 2011.

\begin{abstract}
Kim, K. S., and Beresford, R. M. 2012. Use of a climatic rule and fuzzy sets to model geographic distribution of climatic risk for European canker (Neonectria galligena) of apple. Phytopathology 102:147-157.

A rule-based model was developed to assess climatic risk of European canker (Neonectria galligena), which is a major disease of apple in some temperate zones. A descriptive rule was derived from published observations on climatic conditions favorable for European canker development. Fuzzy set theory was used to evaluate the descriptive rule quantitatively. The amount and frequency of rainfall and the average number of hours between 11 and $16^{\circ} \mathrm{C} /$ day were used as input variables whose values were matched with terms in the rule, e.g., 'high' or 'low'. The degree of a term, e.g., the state of being high or low, to a given input value was determined using a membership function that converts an input value to a number between 0 and 1 . The rule was evaluated by combining

development was represented by the maximum risk index value for 2 months combined. The membership function parameters were adjusted iteratively to achieve a specified level of risk at Talca (Chile), Loughgall (Northern Ireland), East Malling (UK), and Sebastopol (USA), where European canker risk was known. The rule-based model was validated with data collected from Canada, Ecuador, Denmark, Germany, Norway, Poland, Sweden, the Netherlands, New Zealand, and the Pacific Northwest (USA), where European canker has been reported to occur. In these validation areas, the model's risk prediction agreed with reports of disease occurrence. The rule-based model also predicted high risk areas more reliably than the climate matching model, CLIMEX, which relies on correlations between the spatial distribution of a species and climatic conditions. The combination of a climatic rule and fuzzy sets could be used for other applications where prediction of the geographic distribution of organisms is required for climatic risk assessment.
\end{abstract} the degree of the terms associated with monthly climate data. Monthly risk index values derived using the rule were combined for pairs of consecutive months over 12 months. The annual risk of European canker
Additional keywords: biosecurity, climate surfaces, invasion, natural language.
Climate plays an important role in the geographical distribution of species from diverse taxonomic groups (33) and is particularly important for fungal pathogens that cause plant diseases (51). In assessing the risk of a plant pathogen establishing in a region where the pathogen is currently absent, accurate knowledge about climatic suitability for disease development is important to understand likely impacts from the disease (49). This knowledge could facilitate eradication or efficient control of the pathogen (13) or prediction of changes in disease distribution in response to changes in climate (18).

Numerous modeling approaches have been used to analyze the influence of climate on the risk of unwanted organisms establishing in a particular region. Climate matching models including BIOCLIM (6), GARP (43), WORLD (4), SPECIES (34), and CLIMEX (46) have been developed to assess the likelihood of such establishment. For example, the BIOCLIM and GARP models have been used by conservation planners to assess the spatial distribution of a species $(24,42)$ and to produce risk prediction maps for disease management and research $(8,40)$. Pivonia and Yang (36) used the CLIMEX model to predict the geographi-

Corresponding author: K. S. Kim; E-mail address: luxkwang@snu.ac.kr

* The $\boldsymbol{e}$-Xtra logo stands for "electronic extra" and indicates that the online version contains two supplementary tables.

http://dx.doi.org/10.1094/PHYTO-01-11-0018

(C) 2012 The American Phytopathological Society cal areas where soybean rust (Phakopsora pachyrhizi) has the potential to survive during winter.

Current climate matching models predict the potential distribution of an organism in an area where it is currently absent using the degree of similarity of climate in that area to the climate in areas where it does occur currently. This approach only requires correlations between observed geographic distribution of an organism and associated climatic conditions $(43,45)$, rather than knowledge of the influence of climate on the organism's biological processes. For example, the CLIMEX system was designed to predict the geospatial distribution of a species with little use of specific information on interactions between climate and the biology of the species $(45,56)$.

Williamson (53) suggested that such models could result in poor prediction of spatial distribution of invasive species because some species spread into new areas where the climate is different from the native area. While more accurate prediction of plant disease distribution might be achievable using models that incorporate quantitative information about climatic influences on disease development processes, suitable quantitative information is often limited. However, qualitative or descriptive information may be available. For example, Coakley et al. (8) suggested that warm and wet soils would result in reduced severity of take-all under climate change conditions, but provided no quantitative definition of warmness or wetness of soil.

Fuzzy set theory can be used to integrate sources of qualitative and quantitative information. Fuzzy sets are sets whose members have a degree of membership rather than a mutually exclusive 
binomial membership, e.g., yes or no. Suppose $x$ is a member of a fuzzy set $X$. The proposition " $x$ is a member of $X$ " may not be either true or false. Instead, the degree to which $x$ is actually member of $X$ is defined using a membership function that assigns a value between 0 and 1 to each element of the fuzzy set. Fuzzy sets have been used to represent knowledge by stating rules in plain language (2) and constructing a quantitative model from the rules. This approach can deal with uncertainty in simulating biological and environmental processes $(19,32,41)$. Furthermore, in a risk assessment study, the use of fuzzy sets and fuzzy operations would minimize the impact of uncertainty and imprecision in the data as well as in the rules (50).

European canker of apple, caused by the fungus Neonectria galligena, occurs in northern continental Europe and the Pacific Coast in the United States, whereas it is rarely reported in major apple production areas in China $(14,16)$. European canker is one
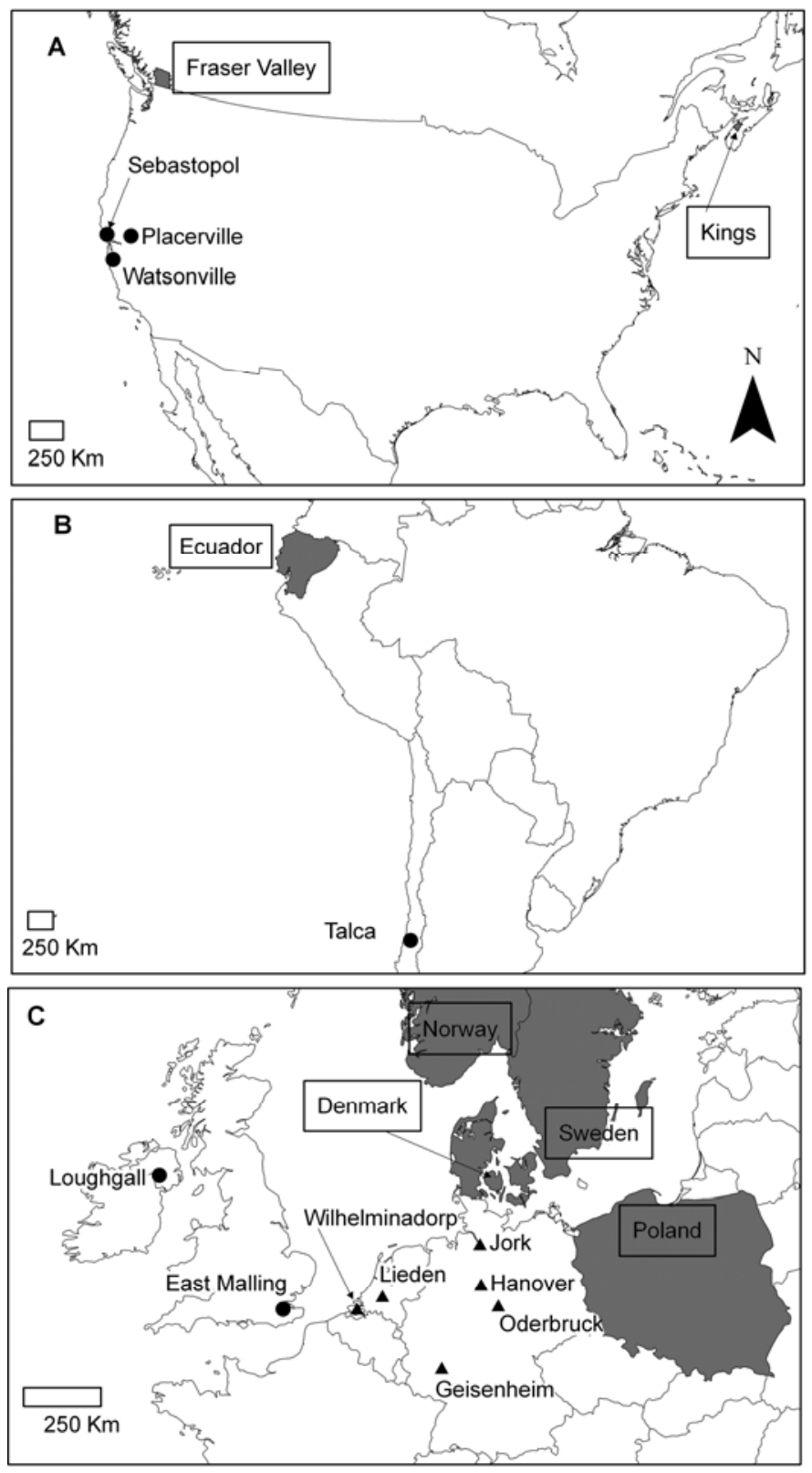

Fig. 1. Location of study areas, including six calibration sites (solid circle), six validation sites (solid triangle), and seven validation regions (shaded area) in A, Canada and the United States; B, Ecuador and Chile; and C, Europe. The validation sites indicate localities at which European canker was reported to be present or absent, whereas the validation regions represent areas in which European canker was reported without specific reference to a locality. of the few diseases in which its geographical distribution has been explained by matching the disease cycle with climate $(3,14)$. The disease is most prevalent in temperate zones with wet and mild conditions (29). Wood cankers establish where frequent rainfall during the leaf fall period facilitates leaf scar infection $(10,23)$. In areas where the summer months have high rainfall frequency and moderate temperatures, cankered trees can provide inoculum for the fruit eye rot phase of the disease $(3,14,28)$.

Because regional climatic influences on European canker development have been documented, this disease provided a good case study to use fuzzy set theory for prediction of geographical distribution of plant disease risk. This study sought to develop and validate a rule-based model using the limited quantitative information that is available on the influence of climate on development of European canker. To compare the rule-based model with one of the current climate matching models, CLIMEX, the worldwide geographical risk of European canker was defined using both these approaches.

\section{MATERIALS AND METHODS}

Existing knowledge about climatic requirements for European canker. European canker development depends on occurrence of favorable climatic conditions over prolonged periods, e.g., 1 to 2 months, to allow time for spore production, spore dispersal, infection, and symptom development to occur $(12,14$, 29,54). Beresford and Kim (3) analyzed published information on European canker risk in relation to long-term climatic data in 12 apple growing regions worldwide. In that study, it was reported that disease risk was greatest when it rained on more than $30 \%$ of days in a month and there was an average of more than $8 \mathrm{~h} /$ day with air temperature between 11 and $16^{\circ} \mathrm{C}$ in the month. European canker was a greater problem in areas where these thresholds were exceeded in several months of the year and where they were exceeded by greater amounts. Although frequency of rainfall or wetness duration has been considered more important than amount of rainfall in determining European canker risk $(12,23$, 48 ), areas in California, with an amount of rainfall $>1,000 \mathrm{~mm}$ per year are considered prone to the disease (12). Autumn is a particularly important time for European canker development because of the presence of susceptible leaf scars during leaf fall, which are the principal site for tree infection $(14,23,29)$.

Study areas. Areas where the presence or absence of European canker was reported were used to calibrate and validate the modeling strategy based on a rule and fuzzy sets (Fig. 1). The level of risk was classified into three groups, i.e., high, moderate, and low. Low risk represented a trivial risk of European canker, e.g., absence of disease in a study area. Areas where serious damage, e.g., death of trees, was reported were classified as high risk areas. Moderate risk indicates a degree of risk between high and low. The study areas were classified into three groups: calibration site, validation site, and validation region. The calibration and validation sites were selected from localities where European canker was reported to be present or absent (Table 1). The validation regions were larger areas within a county or country border without specific reference to a locality (Fig. 1).

Sebastopol (USA), Loughgall (Northern Ireland), East Malling (UK), and Talca (Chile) were used as calibration sites to adjust parameters for the model because there were numerous reports on occurrence of the disease from these areas (Table 1). Placerville and Watsonville (USA) were also used to optimize the model for correct identification of areas where the pathogen is probably present, but the risk of European canker development is negligible because climatic conditions are generally unfavorable for disease development. For example, Dubin and English (12) reported that European canker was present in Sebastopol, whereas it was absent in areas near Placerville and Watsonville although these sites are relatively close to each other (Fig. 1). 
European canker has caused serious problems including fruit rot and death of trees in various parts of Europe (17). For example, Wessel (52) reported that European canker was severe at Jork and Oderbrück, less severe at Hanover and did not develop at Geisenheim in Germany. European canker occurs in the Netherlands including Wilhelminadorp and Lienden (15). Thus, sites in Germany and the Netherlands where European canker has been reported $(15,52)$ were used as validation sites.

The validation regions comprised parts of countries in Europe, North and South America, and New Zealand where European canker has been reported without detail about its severity or seasonal development (Fig. 1). For example, European canker has been reported in European areas including mid-Zealand in Denmark (22), northwestern Poland (57), coastal regions in Norway (38), and southern Sweden (44). In North and South America, European canker has been reported in apple orchards. Braun (5) reported that incidence of European canker was $>30 \%$ on susceptible apple trees in Kings County, Nova Scotia, Canada. Punja and Ormrod (37) reported that European canker caused serious problems in coastal areas in British Columbia, Canada, including Fraser Valley area. In Ecuador, European canker has been found in apple orchards (31). In the western part of the Pacific Northwest United States including Oregon and Washington states, European canker has been reported (14), whereas the disease has rarely been reported at sites in the central part of the region (58).

In New Zealand, information about regional distribution of European canker indicates that it has caused problems in the wet areas in the North Island, including Auckland (1). The disease sometimes occurs around Nelson and is known to apple growers around Gisborne (3). In contrast, the disease does not cause a problem in the southeastern part of the North Island, e.g., Hastings, or the eastern part of the South Island, e.g., Blenheim, Christchurch, and Cromwell (R. Scheper, unpublished data).

Climate surfaces used as inputs to the rule-based model. Analysis of the climatic risk for development of a disease requires data sets containing appropriate variables measured with a time resolution relevant to that disease. The variables must be available for sites of interest, either using nearby weather stations or interpolated climate surfaces. In the present study, global climate surfaces were used as inputs to the rule-based model to estimate climatic variables at the calibration and validation sites where information about European canker was available (Table 1). In a validation region, the climate surfaces were used to calculate the climatic risk of European canker at each grid point and to determine maximum risk within the boundary of the region. The climate surfaces were obtained from the Climatic Research Unit (CRU), University of East Anglia, Norwich (30). The spatial resolution of the surfaces was 10 arc min. The CRU surfaces were derived by spatial interpolation from 30-year station records from 1961 to 1990.

The climate surfaces were monthly rainfall frequency (number of days with $>0.1 \mathrm{~mm}$ of rainfall), monthly total precipitation $(\mathrm{mm})$, monthly mean temperature and mean diurnal temperature range $\left({ }^{\circ} \mathrm{C}\right)$. Three variables relevant to European canker were derived from these surfaces $(3,12)$ : rainfall frequency (percentage of days/month with rainfall), rainfall amount ( $\mathrm{mm} / \mathrm{month})$, and temperature range (number of hours/day with air temperature between 11 and $16^{\circ} \mathrm{C}$ ).

Temperature surfaces for monthly mean temperature $T M$ and mean diurnal temperature range $T R$ were used to derive the temperature range variable, which required estimates of hourly temperature to calculate number of hours between 11 and $16^{\circ} \mathrm{C}$ each day. The WAVE method $(3,7,39)$ was used to estimate hourly temperature using daily average temperature $T_{A V G}$ and daily diurnal temperature range $T_{R N G}$. Because there was no daily data available in the global temperature surfaces, the values of $T M_{m}$ and $T R_{m}$ were used as surrogate inputs to $T_{A V G}$ and $T_{R N G}$, respectively, in a given month $m$.

Formulation of a rule-based model using fuzzy sets. A rule to represent climatic suitability for the development of European canker was defined from existing knowledge on the monthly temperature and rainfall conditions under which the disease mostly occurs $(3,12,23,48)$. The climatic rule was defined in natural language to represent wet and mild conditions for European canker development under the assumption that adequate inoculum and susceptible hosts are available as follows: "rainfall is frequent or rainfall is heavy, and temperature is mild."

To evaluate the climatic rule statement, fuzzy sets that represent the terms frequent, heavy, and mild were defined using membership functions $\mu_{D}, \mu_{P}$, and $\mu_{T}$, respectively (Fig. 2). These membership functions converted an input value to a value between 0 and 1 , which represents the degree of the term associated with the corresponding input variable. For example, $100 \mathrm{~mm}$ of rainfall was equivalent to heavy at the degree of 0.5 (Fig. 2). Further description of fuzzy sets and their operation can be found in Klir and Yuan (20).

The connectives in the climatic rule statement, i.e., and and or, were defined as follows:

$$
\begin{gathered}
a \quad \text { and } \quad b=a \cdot b \\
a \quad \text { or } \quad b=\max (a, b)
\end{gathered}
$$

where $a$ and $b$ are the degree of membership. Using equations 1 and 2 , the rule statement was rewritten to determine the value of $R_{m}$ as follows:

TABLE 1. Calibration and validation sites in Chile (CH), Germany (DE), The Netherlands (NL), North Ireland (NI), United Kingdom (UK), and the United States (US) where occurrence of European canker was reported

\begin{tabular}{llcl}
\hline Locality & Geographic coordinate & Risk $^{\mathrm{a}}$ & References \\
\hline Calibration sites & & & \\
East Malling, UK & $51^{\circ} 16^{\prime} 49^{\prime \prime} \mathrm{N} 0^{\circ} 26^{\prime} 56^{\prime \prime} \mathrm{E}$ & Moderate & $9,29,47$ \\
Loughgall, NI & $54^{\circ} 24^{\prime} 40^{\prime \prime} \mathrm{N} 6^{\circ} 36^{\prime} 00^{\prime \prime} \mathrm{W}$ & High & $9,29,47$ \\
Sebastopol, US & $38^{\circ} 24^{\prime} 07^{\prime \prime} \mathrm{N} 122^{\circ} 49^{\prime} 25^{\prime \prime} \mathrm{W}$ & Moderate & $12,28,54$ \\
Talca, CH & $35^{\circ} 25^{\prime} 21^{\prime \prime} \mathrm{S} 71^{\circ} 39^{\prime} 23^{\prime \prime} \mathrm{W}$ & High & 25 \\
Watsonville, US & $36^{\circ} 54^{\prime} 36^{\prime \prime} \mathrm{N} 121^{\circ} 45^{\prime} 24^{\prime \prime} \mathrm{W}$ & Low & 12 \\
Placerville, US & $38^{\circ} 43^{\prime} 46^{\prime \prime} \mathrm{N} 120^{\circ} 47^{\prime} 57^{\prime \prime} \mathrm{W}$ & Low & 12 \\
Validation sites & & & 52 \\
Jork, DE & $53^{\circ} 31^{\prime} 56^{\prime \prime} \mathrm{N} 9^{\circ} 40^{\prime} 49^{\prime \prime} \mathrm{E}$ & High & 52 \\
Hanover, DE & $52^{\circ} 22^{\prime} 19^{\prime \prime} \mathrm{N} 9^{\circ} 44^{\prime} 08^{\prime \prime} \mathrm{E}$ & Moderate & \\
Oderbrück, DE & $51^{\circ} 46^{\prime} 28^{\prime \prime} \mathrm{N} 10^{\circ} 33^{\prime} 12^{\prime \prime} \mathrm{E}$ & High & \\
Geisenheim, DE & $49^{\circ} 59^{\prime} 02^{\prime \prime} \mathrm{N} 7^{\circ} 57^{\prime} 59^{\prime \prime} \mathrm{E}$ & Low & \\
Wilhelminadorp, NL & $51^{\circ} 31^{\prime \prime} 47^{\prime \prime} \mathrm{N} 3^{\circ} 53^{\prime} 56^{\prime \prime} \mathrm{E}$ & High & 15 \\
Lienden, NL & $51^{\circ} 56^{\prime} 48^{\prime \prime} \mathrm{N} 5^{\circ} 03^{\prime} 11^{\prime \prime} \mathrm{E}$ & Moderate & 15 \\
\hline
\end{tabular}

${ }^{a}$ Sites where Neonectria galligena caused serious damages in apple production including death of trees were classified as high risk area. Low risk level indicates a trivial risk of $N$. galligena development. Moderate risk represents a risk level between high and low levels. 


$$
R_{m}=\max \left(\mu_{D}, \mu_{P}\right) \cdot \mu_{T}
$$

where $R_{m}$ is a risk index in a given month $m . R_{m}$ was calculated using the monthly climate data. Because the values of $\mu$ were between 0 and $1, R_{m}$ also lies between 0 and 1 . It was assumed that monthly climate conditions were favorable for European canker development when $R_{m}>0.5$.

Climate conditions were evaluated using monthly climate data, although favorable climate conditions could occur within a calendar month or over two consecutive months. Thus, periods of two consecutive calendar months were considered a relevant timeframe in a season (3) to quantify favorable climatic conditions for development of European canker. The risk indices $R_{m n}$ were obtained for two consecutive months at a time, $m$ and $n$, and the monthly risk indices were combined using a fuzzy union operation as follows (20):

$$
R_{m n}=R_{m}+R_{n}-R_{m} \cdot R_{n}
$$

The risk of European canker was assumed to be high when favorable climate conditions occurred for two consecutive months.

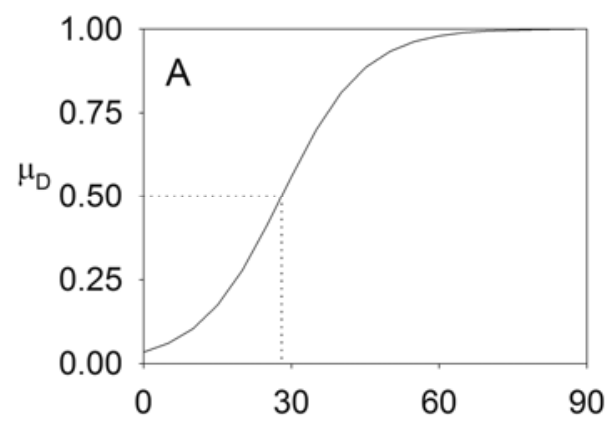

The number of days with rain (\%)
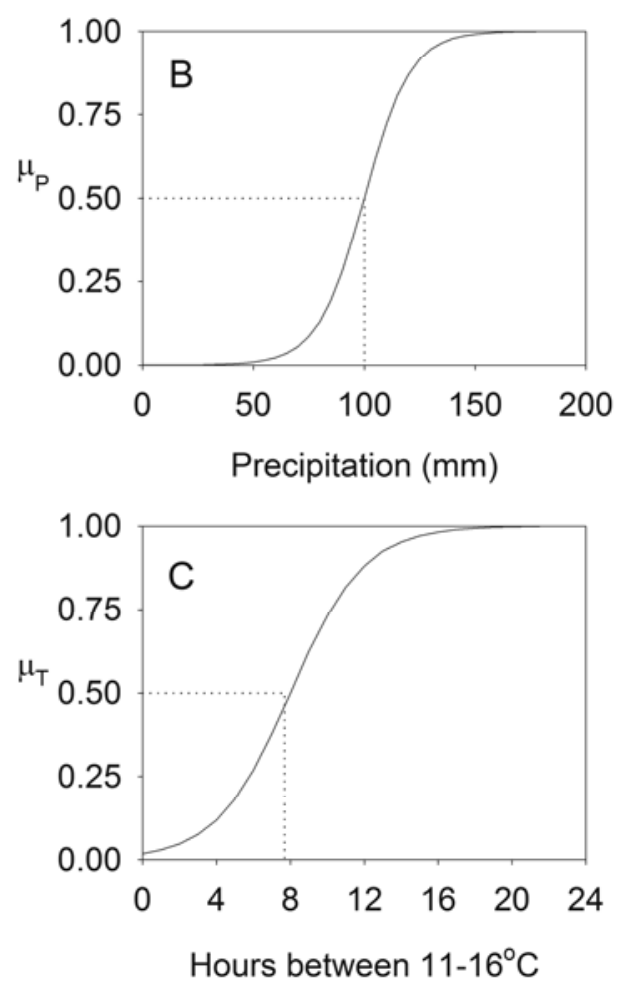

Fig. 2. Graphical representation of membership functions of terms in the rule to assess the climatic risk of European canker in a month. Each membership function represents the degree of $\mathbf{A}$, frequent rainfall $\left(\mu_{D}\right) ; \mathbf{B}$, heavy rainfall $\left(\mu_{P}\right)$; and $\mathbf{C}$, moderate temperature $\left(\mu_{T}\right)$. The number of days with rain $(\%)$, precipitation $(\mathrm{mm})$, and average daily hours between 11 and $16^{\circ} \mathrm{C}(\mathrm{h})$ in a month were used as input to the corresponding membership functions.
When $R_{m}>0.5$ occurs for 2 months in a row, $R_{m n}>0.75$ is obtained. Therefore, the $R_{m n}$ value of 0.75 was chosen to represent high risk of European canker for the prolonged period when adequate inoculum and susceptible hosts are available.

The climatic risk index $R$, which represents the climatic risk of European canker in a given area, was assumed to be the highest risk of European canker development within a season. Among 12 values of $R_{m n}$, its maximum value was chosen to determine the value of $R$ as follows:

$$
R=\max \left\{(m, n) \in M N: R_{m n}\right\}
$$

where $M N$ is a set of two consecutive months, i.e., ([January, February], [February, March], ..., [December, January]). Using equation 5 made it possible to consider periods for more than 2 months with high risk of the disease.

Definition of membership functions. The shape of a membership function for a fuzzy set can be chosen using the opinion of an expert or experimental data (20). Because European canker occurs mostly under wet and mild conditions, it was assumed that the disease risk would increase with increasing amount or frequency of rainfall and increasing frequency of mild temperature conditions. In addition, it was preferable to use a function that depends on a small number of parameters. For the terms in the climatic rule statement, sigmoid curves were used as membership functions because this curve is monotonically increasing and requires two parameters. Membership functions of frequent and heavy, $\mu_{D}$ and $\mu_{P}$, respectively, were defined as follows:

$$
\begin{gathered}
\mu_{D}\left(D_{m}\right)=\left\{1+\exp \left[-S_{D} \cdot\left(D_{m}-K_{D}\right)\right]\right\}^{-1} \\
\mu_{P}\left(P_{m}\right)=\left\{1+\exp \left[-S_{P} \cdot\left(P_{m}-K_{P}\right)\right]\right\}^{-1}
\end{gathered}
$$

where $D_{m}$ and $P_{m}$ indicate the frequency of days with rain (\%) and precipitation $(\mathrm{mm})$ in a month $m$, respectively. $K$. and $S$. were parameters for the membership function, which represent a threshold of favorable conditions and a measure of risk increase for European canker development, respectively. To represent the temperature variable in the climatic rule statement, the average number of hours between 11 and $16^{\circ} \mathrm{C}$ for 24 -h periods in a month was used. The mild membership function $\mu_{T}$ was defined as follows:

$$
\mu_{T}\left(T_{m}\right)=\left\{1+\exp \left[-S_{T} \cdot\left(T_{m}-K_{T}\right)\right]\right\}^{-1}
$$

where $T_{m}$ indicates daily average hours between 11 and $16^{\circ} \mathrm{C}$ in a month $m$.

Parameter optimization for the rule-based model. The values of $K$ parameters were determined using existing observations. Values of $K_{D}$ and $K_{T}$ used in this study were assumed to be $28 \%$ of days in a month and $7.7 \mathrm{~h}$ /day between 11 and $16^{\circ} \mathrm{C}$, respectively, following Beresford and Kim (3) (Appendix). The value of $K_{P}$ was assumed to be $100 \mathrm{~mm}$ per month, approximating an annual precipitation over 1,000 $\mathrm{mm}$, which was identified as being associated with European canker development in California (12).

The $S$ parameters were adjusted to achieve $R_{m}$ values that resulted in $R_{m n}>0.75$ for a period during which the risk of European canker was known to be high at calibration sites (Table 1). $S$ parameters were also optimized using $R$ values determined from the climate surfaces and long-term daily weather data obtained at Watsonville and Placerville where daily temperature and precipitation data were available. These long-term monthly averages were used as input to the rule-based model to determine $R$ values, which were designated $R_{d}$ (Appendix).

The values of $S$ parameters were determined by an iterative process to maximize the degree of agreement statistic $k$ between high risk periods of European canker using previous reports and $R_{m n}$ values, and to minimize the differences between $R$ and $R_{d}$ values. At first, a set was defined for the $S$ parameter of each $\mu$ to represent a search space for the parameter. Then, each 
element of the set was used as $S$ parameter values to calculate $R_{m n}$ values and the $k$ statistic. The $k$ statistic was calculated as follows (11):

$$
k=\left(\sum_{i=0}^{1} \sum_{j=0}^{1} \frac{C_{i j}}{N}-\sum_{i=0}^{1} \sum_{j=0}^{1} \frac{C_{i j}}{N} \cdot \sum_{j=0}^{1} \frac{C_{j i}}{N}\right) /\left(1-\sum_{i=0}^{1} \sum_{j=0}^{1} \frac{C_{i j}}{N} \cdot \sum_{j=0}^{1} \frac{C_{j i}}{N}\right)
$$

where $C_{i j}$ represents the number of cases predicted high $(i=1)$ or low $(i=0)$ by the rule-based model when actually high $(j=1)$ or low $(j=0)$ risk of European canker was reported during the 2 month periods at calibration sites. For example, $C_{11}$ indicates the number of cases such that the rule-based model predicted high risk of European canker for periods when the high risk of European canker, e.g., death of tree, was reported across calibration sites. At each calibration site, the bimonthly predictions of European canker risk were compared with the observations (Table 1 ) and its results were used to determine $C_{i j}$. The total number of cases was $N=72$.

Using reports on temporal occurrence of European canker, the high risk periods for the disease were estimated for two consecutive months at a time (Table 1). A range of $S$ parameter values was set and each combination was examined iteratively to maximize the value of the $k$ statistic. After the parameters for membership functions were determined, further analysis was performed to investigate the interaction of variables in the climate rule, and particularly, the relative influence of frequent or heavy rainfall on risk at each calibration site. The distribution of moderate to high risk $\left(R_{m}>0.5\right)$ was plotted at each calibration site for 12 months in relation to ranges of values of $T_{m}, P_{m}$, and $D_{m}$.

Validation of the rule-based model. The rule-based model was validated using reports about occurrence of European canker in eight countries (Fig. 1). At validation sites, the $R$ value was determined at a grid cell of climate surfaces. In validation regions, however, a range of $R$ values was obtained from each grid point within the boundary of the region. Thus, minimum, maximum, and average values of $R$ were calculated for each validation region. Additional climatic risk assessment of the disease was performed for the Pacific Northwest United States and New Zealand, where reports on occurrence of the disease were restricted to some parts of those regions. For each country, regional risk maps were generated using the global climate surfaces as inputs to the rule-based model. The Geographic Resources Analysis Support
System (GRASS) was used to compute $R$ values using the climate surfaces. GRASS is a geographic information system used for geospatial data management and analysis, map production, spatial modeling, and visualization (http://grass.osgeo.org/).

Comparison with a climate matching approach. CLIMEX version 3.02 (Hearne Scientific Software, Melbourne, Australia) was used to compare a climate matching method with the rulebased approach using fuzzy sets. The CLIMEX system uses a default database derived from the global temperature and rainfall surfaces generated from the Climatic Research Unit (CRU). These surfaces have a 30 arc min spatial resolution. The default surfaces were used to predict the geospatial distribution of European canker.

The CLIMEX system consists of a set of models to predict geographical distribution of organisms and includes a "compare location' module. Although the rule-based model was developed using the six calibration sites, six was not enough to perform the predictions using CLIMEX because these may not have represented the full range of climatic conditions associated with the disease (21). Thus, six calibration and six validation sites used for the rule-based model were combined to determine parameters of the compare location module.

In the compare location module, an ecoclimatic index (EI) was determined to represent overall climatic risk at a site of interest (46). The value of EI was calculated by averaging weekly values of a population growth index (GI) and multiplying stress indices, which represent population growth of an organism and environmental stresses due to dry or hot climate, respectively. The parameters of the CLIMEX model were heuristically adjusted to obtain the EI values that reflected the known occurrence of European canker at grid points near the calibration and validation sites. To examine the temporal risk pattern of European canker for the CLIMEX model, weekly values of GI were compared with the $R_{m n}$ values. To evaluate the performance of the CLIMEX model, the EI values were examined in the validation regions used.

\section{RESULTS}

Calibration of the rule-based model. The $S$ parameters for the membership functions of $\mu_{D}, \mu_{P}$, and $\mu_{T}$ were determined to be 12 , 0.095 , and 0.275 , respectively, which resulted in the $k$ value of 0.81 . Figure 2 shows the optimized $\mu_{D}, \mu_{P}$, and $\mu_{T}$ after values of $S$
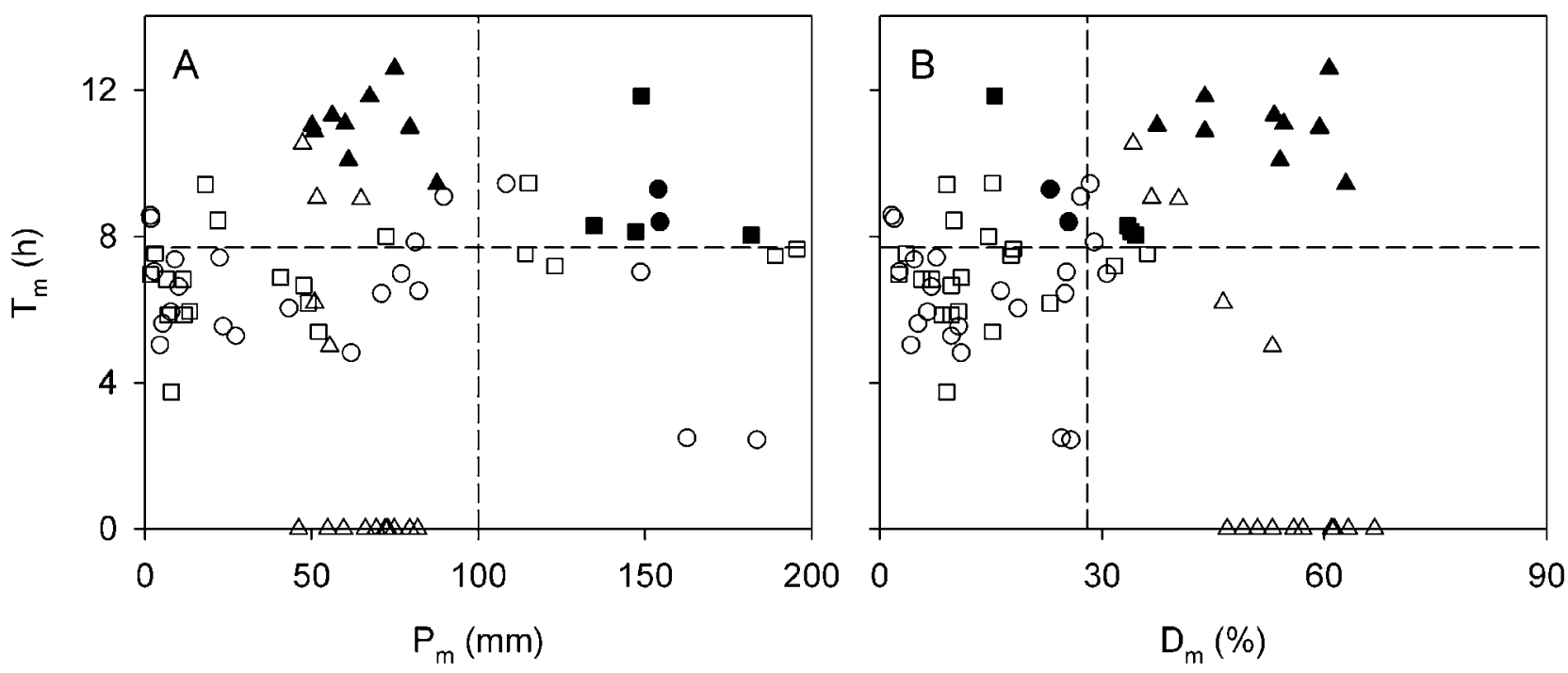

Fig. 3. Analysis showing the response of the monthly risk index $R_{m}$ to heaviness of rainfall $\left(P_{m} ; \mathrm{mm}\right)(\mathbf{A})$ and frequency of rain days $\left(D_{m} ; \%\right)(\mathbf{B})$ for daily average hours between 11 and $16^{\circ} \mathrm{C}\left(T_{m} ; \mathrm{h}\right)$ in predicting the risk of European canker. Points indicate $R_{m}$ at the six calibration sites, which are represented by three different symbols: East Malling and Loughgall (triangle), Sebastopol and Talca (square), and Placerville and Watsonville (circle). Open symbols represent low $R_{m}$ values ( 0.0 to 0.5$)$, whereas solid symbols indicate moderate to high $R_{m}$ values (0.5 to 1.0). Vertical and horizontal lines indicate $100 \mathrm{~mm}$ of rainfall (A), $28 \%$ of days with rain $(\mathbf{B})$, and $7.7 \mathrm{~h} /$ day with temperatures of 11 to $16^{\circ} \mathrm{C}$, respectively. 
parameters were determined. The analysis of $R_{m}$ in relation to rainfall frequency $\left(D_{m}\right)$, temperature range $\left(T_{m}\right)$, and precipitation amount $\left(P_{m}\right)$ showed that the climatic pattern resulting in high risk of European canker differed between sites, particularly in relation to either heavy rainfall or frequent rainfall. For example, for the sites with heavy rainfall in a relatively short period of time (Talca and the California sites), $R_{m}$ was $>0.5$ in months with $P_{m}>$ $130 \mathrm{~mm}$ given $T_{m}>8 \mathrm{~h} /$ day. In contrast, for the sites with regular rainfall over a long period (East Malling and Loughgall), $R_{m}$ values $>0.5$ occurred in months with $D_{m}>37 \%$ given $T_{m}>$ 8 h/day (Fig. 3).

The temporal pattern of $R_{m n}$ values (i.e., the predicted climatic risk of European canker for two consecutive months) showed substantial differences between calibration sites (Fig. 4). At Loughgall and East Malling, $R_{m n}$ was $>0.75$, over a growing season, i.e., from spring to autumn months. On the other hand, $R_{m n}$ was $>0.75$ at Talca only for autumn months, e.g., April and May. At the California sites including Sebastopol, Watsonville, and Placerville, $R_{m n}$ was at maximum during winter months.

The $R$ value (maximum $R_{m n}$ ), which ranges from 0 to 1 , was greatest in Loughall (0.93) followed by Talca (0.87), East Malling (0.82), and then Sebastopol (0.77) (Table 2). The $R$ value was very low at Watsonville (0.62) and was 0.75 at Placerville. When daily data were used as inputs at these two California sites, $R_{d}$ and $R$ values were similar (0.63) at Watsonville, whereas the $R_{d}$ value was considerably lower (0.63) than the $R$ value at Placerville (Fig. 4B). The pattern of seasonal variation in predicted risk of European canker remained the same for these sites between $R_{d}$ and $R$ values.

TABLE 2. Climatic risk indices at validation sites using the rule-based model (R) and the CLIMEX model (EI)

\begin{tabular}{lll}
\hline Locality & $\mathrm{R}^{\mathrm{a}}$ & $\mathrm{EI}^{\mathrm{b}}$ \\
\hline Calibration site & & \\
East Malling & 0.82 & 51 \\
Loughgall & 0.93 & 57 \\
Sebastopol & 0.77 & 39 \\
Talca & 0.87 & 36 \\
Watsonville & 0.59 & 38 \\
Placerville & 0.75 & 0 \\
Validation site & & \\
Jork & 0.86 & 43 \\
Hanover & 0.83 & 41 \\
Oderbrück & 0.88 & 45 \\
Geisenheim & 0.79 & 35 \\
Wilhelminadorp & 0.95 & 50 \\
Lienden & 0.86 & 45 \\
\hline
\end{tabular}

${ }^{a}$ The value $>0.75$ indicates nontrivial risk of European canker.

${ }^{b}$ The value $>35$ represents nontrivial risk of European canker.

c Validation sites for the rule-based model were used as calibration sites for the CLIMEX model.
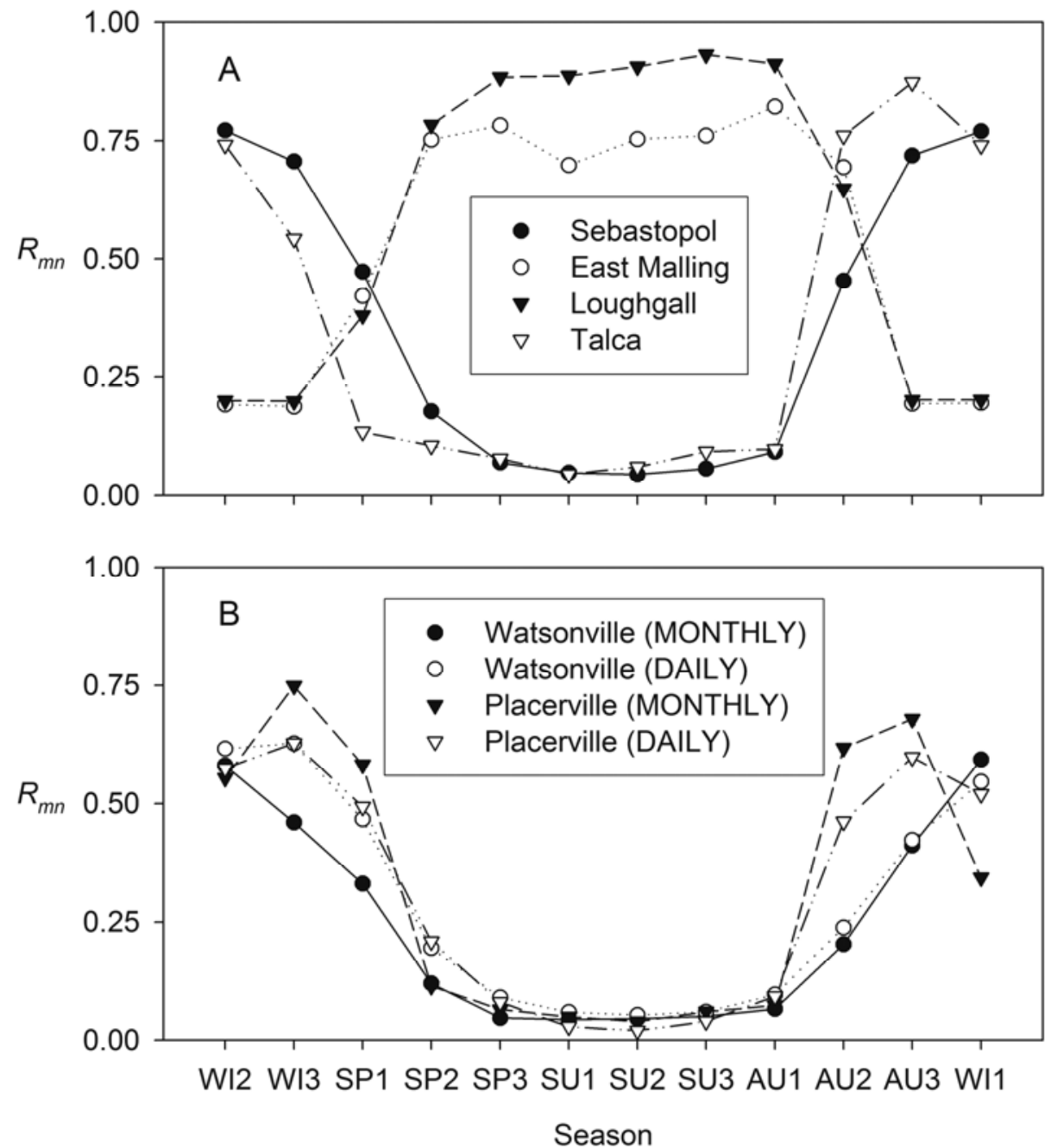

Fig. 4. The risk index $R_{m n}$ for two consecutive months at calibration sites including A, Sebastopol, Talca, East Malling and Loughgall and B, Watsonville and Placerville. MONTHLY and DAILY indicate risk indices determined using global climate surfaces and daily weather data, respectively. Each point is the $R_{m n}$ value plotted against the first of two consecutive months. To represent seasons in both northern and southern hemisphere at the same time, each calendar month is indicated by the first two letters of its corresponding season and the ordering of month (1 to 3) within the season. For example, WI 2 represents January and July at sites in northern and southern hemisphere, respectively. 
Validation of the rule-based model. In northwestern Europe, $R$ values differed by regions, which corresponded with reported geographic distribution of European canker risk (Fig. 5A). For example, $R$ values in Germany were $>0.85$ in the coastal area north of Jork and in the Harz mountain area near Oderbrück. It was lower ( 0.80 to 0.85$)$ around Hanover. There were patches

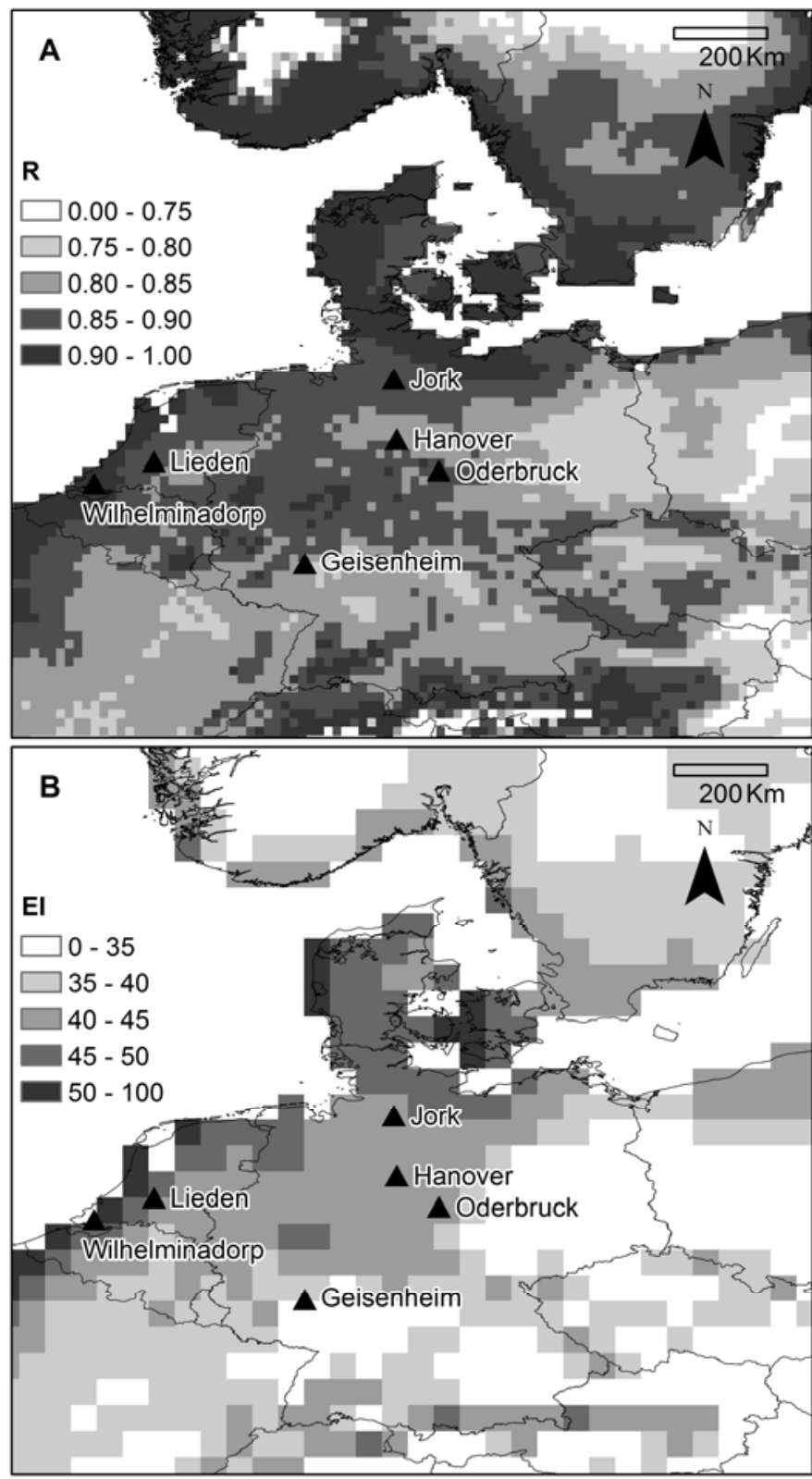

Fig. 5. Maps of risk indices for development of European canker using A, the rule-based model $(R)$ and $\mathbf{B}$, the CLIMEX model (EI) in north-western Europe. Areas with $R>0.75$ and EI $>35$ represent nontrivial risk of European canker, respectively. including Geisenheim where $R$ values were relatively low (0.75 to $0.80)$. Although these values of $R$ indicated high risk of European canker at sites where no disease was reported, it seemed that such false predictions resulted from errors of climate surfaces. For example, the $R_{d}$ value was 0.71 at a site near Geisenheim when local daily weather data were used as inputs to the rule-based
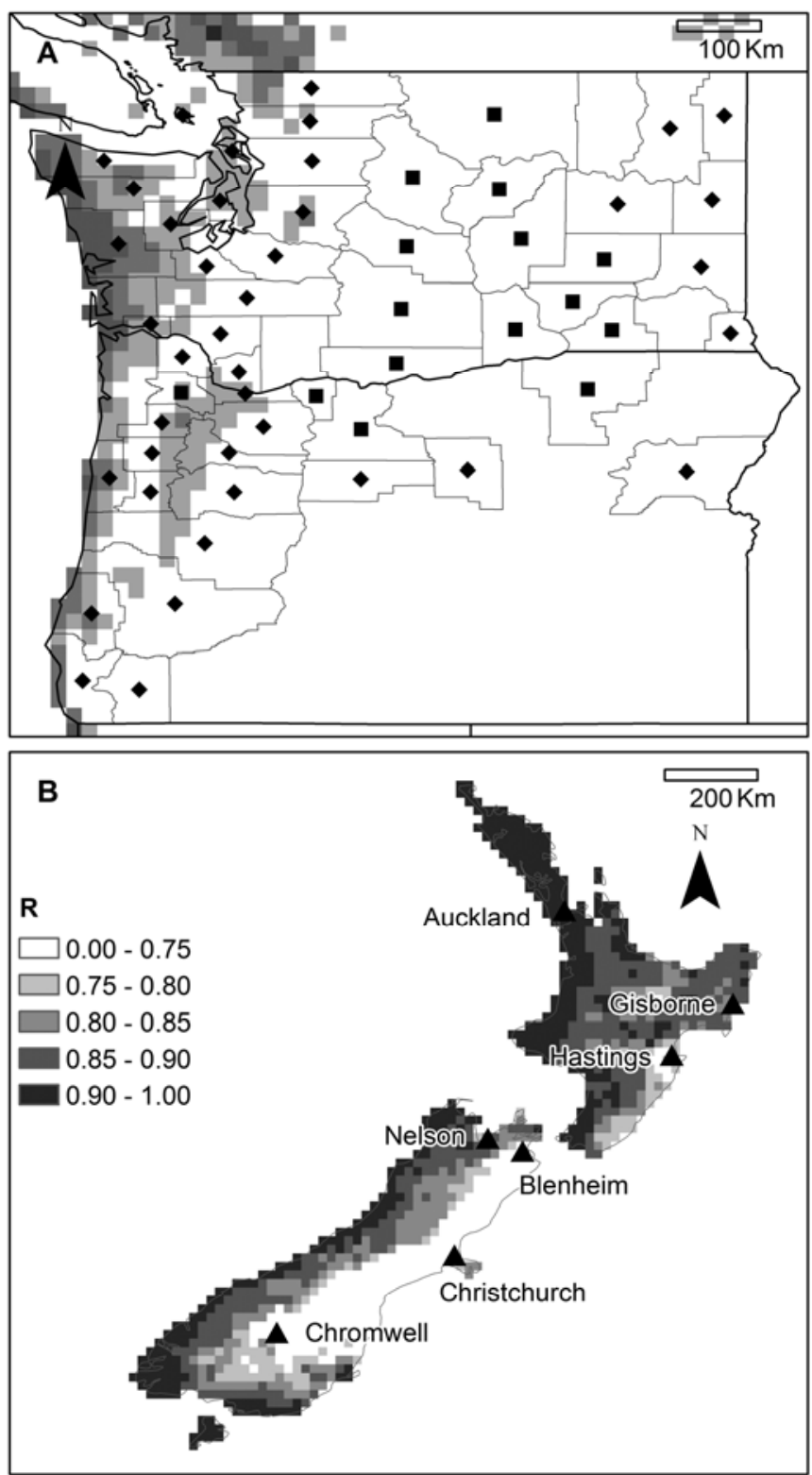

Fig. 6. Maps of risk index $(R)$ for development of European canker using the rule-based model in A, the Pacific Northwest U.S. and B, New Zealand. Areas with $R>0.75$ represent nontrivial risk of European canker. Square symbols in A represent counties that have large ( $>200 \mathrm{ha}$ ) apple production area, whereas diamond symbols indicates counties with small apple production area.

TABLE 3. Climatic risk indices in validation regions using the rule-based model (R) and the CLIMEX model (EI)

\begin{tabular}{|c|c|c|c|c|c|c|}
\hline \multirow[b]{2}{*}{ Locality } & \multicolumn{3}{|c|}{$\mathrm{R}^{\mathrm{a}}$} & \multicolumn{3}{|c|}{$\mathrm{EI}^{\mathrm{b}}$} \\
\hline & Min. & Mean & Max. & Min. & Mean & Max. \\
\hline Fraser Valley ${ }^{\mathrm{c}}$ & 0.51 & 0.71 & 0.89 & 25.0 & 35.7 & 41.0 \\
\hline Kings $^{d}$ & 0.74 & 0.77 & 0.80 & 26.0 & 26.0 & 26.0 \\
\hline Ecuador & 0.16 & 0.38 & 0.93 & 0.0 & 9.7 & 97.0 \\
\hline
\end{tabular}

a The value $>0.75$ indicates nontrivial risk of European canker

b The value $>35$ represents nontrivial risk of European canker.

c Fraser Valley County, British Columbia, Canada.

d Kings County, Nova Scotia, Canada. 
model (Appendix). The $R$ values at Jork, Oderbrück, and Hanover were 5, 7, and 2 greater, respectively, than that at East Malling, whereas the $R$ value at Geisenheim was $4 \%$ lower than that at East Malling (Table 2). In the other European areas where European canker has been reported, including Denmark, Norway, Sweden, and northwestern Poland, the $R$ value ranged from 0.80 to 0.95 (Fig. 5A).

The validation regions in North and South America where European canker has been reported tended to have $R$ values of $>0.75$ (Table 3). In Canada, $R$ values were $>0.80$ and $>0.90$ at some sites in Kings and Fraser Valley counties, respectively. $R$ values were $>0.90$ in some mountainous parts of Ecuador (Table $3)$. $R$ values were high ( $>0.75)$ only in the western part of Oregon and Washington, which agreed with previous observations (Fig. 6A).

In New Zealand, $R$ values were generally high $(>0.9)$ at Auckland but were lower ( 0.8 to 0.9$)$ in areas near Gisborne and even lower $(0.7$ to 0.8$)$ in the southeastern North Island around Hastings (Fig. 6B). $R$ values were also high along the western and southern coastal parts of the South Island including Nelson (0.86), but were low $(<0.7)$ in most parts of the South Island to the east of the main mountain ranges, including Blenheim (0.55), Christchurch (0.62), and Cromwell (0.42).

Comparison with the CLIMEX model. The climatic risk index (EI) $>35$ indicated nontrivial risk of European canker development with optimized parameters. Overall, the CLIMEX model tended to show similar temporal patterns of European canker risk compared with the rule-based model (Figs. 4 and 7). However, there were periods during which the models disagreed at some sites. For example, weekly population GI values at
Watsonville were relatively low during winter, whereas the $R_{m n}$ values were high during the same period. At Talca, the weekly GI values were high during spring, whereas the $R_{m n}$ values were low during the same period. At East Malling, weekly GI values dropped substantially during mid- to late-summer, whereas $R_{m n}$ values remained relatively high during that period.

The relative magnitude of estimated risk for European canker at the calibration and validation sites differed somewhat between the CLIMEX (EI values) and rule-based ( $R$ values) models (Fig. 5B; Table 2). For example, at the calibration sites, while both models predicted greatest risk for Loughgall, the EI value for East Malling was greater than that for Talca, whereas the $R$ value for Talca was greater than that for East Malling.

The CLIMEX model predicted the risk of European canker reasonably in some validation regions (Table 3 ). For example, the EI values were $>40$ in large areas of Fraser Valley County. The EI values exceeded 90 in some areas in Ecuador. The CLIMEX model also predicted high risk in the western part of Oregon and Washington (Fig. 8A). However, the EI values disagreed with current observations in some other validation regions. For example, the EI values were $<30$ in Kings County. In New Zealand, the EI values were $>35$ in the eastern South Island where the disease rarely occurred, whereas $R$ values were low, e.g., $<0.7$ in that area (Fig. 8B).

\section{DISCUSSION}

This study demonstrated that the rule-based model, using a rule and fuzzy sets, gave reliable prediction of the climatic risk of
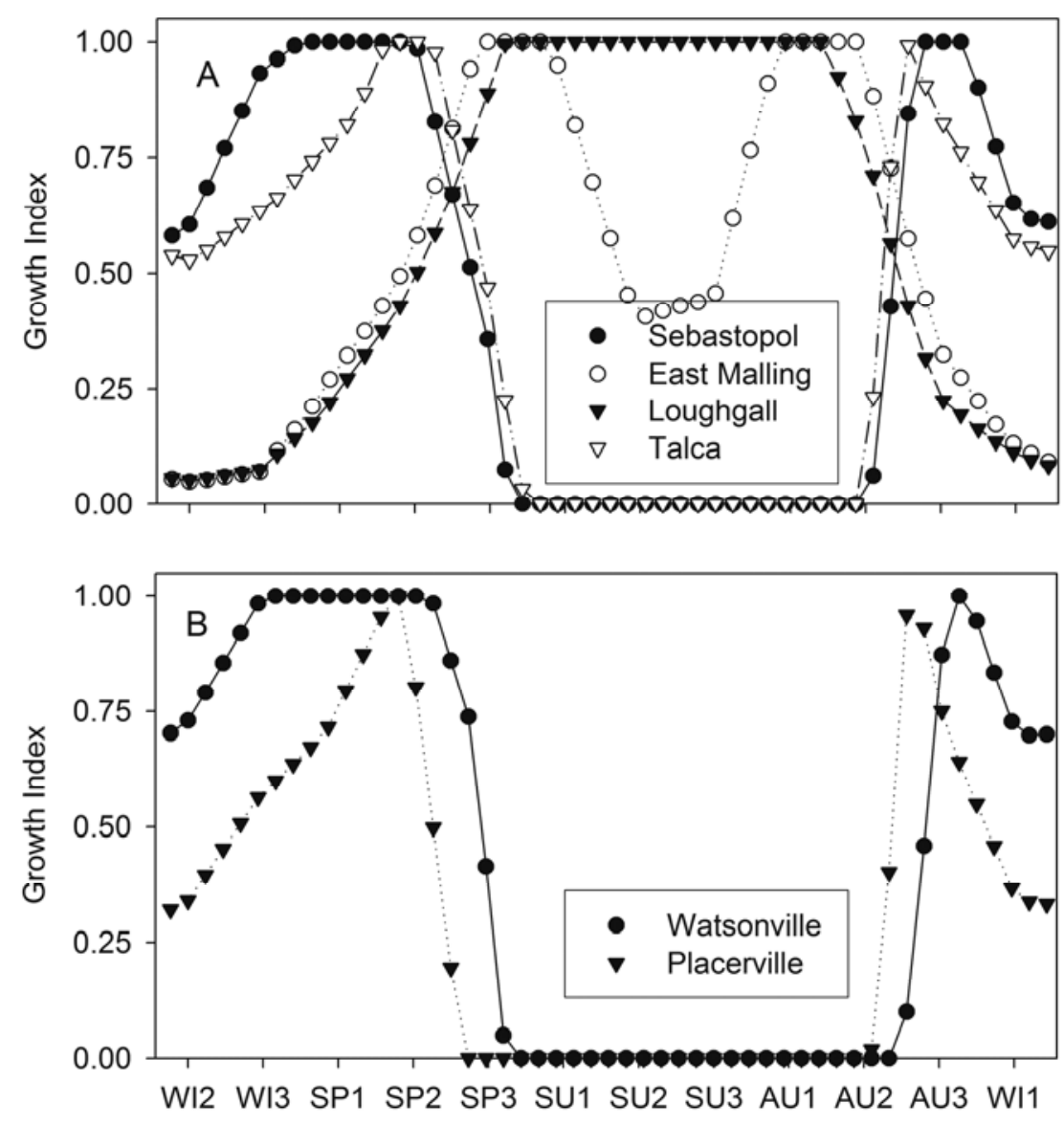

Season

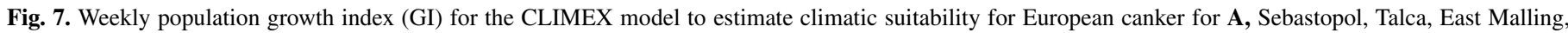

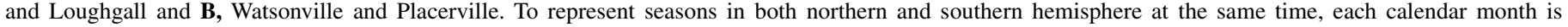

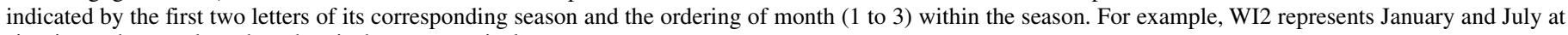
sites in northern and southern hemisphere, respectively. 
European canker at sites in different parts of world. The membership functions gave only an approximation of the actual underlying response of European canker development to the climatic variables. The rule also gave only an approximation of the way the climatic variables would actually interact to affect European canker development. Nevertheless, the predicted risk of European canker using the rule-based model agreed with current observations in regions where no calibration sites were located. For example, the rule-based model identified high risk areas of Germany where risk has been reported to be high (17) and low risk areas in the Pacific Northwest and New Zealand where European canker has rarely been reported.

Beresford and Kim (3) used rainfall frequency and temperature range variables to identify common climatic conditions conducive to European canker at the same calibration sites used in the present study. The present study included rainfall amount as an additional input variable for the rule-based model. Rainfall amount had been found to reflect European canker development in northern California (12). The addition of rainfall amount and its use in the rule-based model with the or connective, made the rule-based model less vulnerable to underestimated rainfall frequency in the global surfaces. In Figure 3, it was shown that when high monthly precipitation (e.g., $>100 \mathrm{~mm}$ ) was associated with a small number of days with rain (e.g., $<30 \%$ ), $R_{m}$ values were mostly dependent on the amount of rainfall, rather than frequency of rainfall. In regions with relatively intense rainfall like this, our approach would minimize the impact on the risk prediction in relation to underestimated precipitation frequency. At Talca, for example, the climate surfaces indicated that rainfall amount was $149 \mathrm{~mm}$ and $196 \mathrm{~mm}$ for May and June, respectively, whereas the frequency of rainfall was less than $20 \%$ for the same period.

The weather variable, duration of free moisture (leaf wetness), has been used to reflect water availability requirements for European canker development in relation to disease risk prediction models $(23,55)$. However, as no global surface of wetness duration was available, that variable could not be used for the rulebased model. In a region where leaf wetness data are available, the rule-based model could be modified to use wetness duration as an input variable.

The rule-based model was deliberately designed to tend to overpredict European canker risk in order to accommodate uncertainty and imprecision in the climate data, as well as limitations in local knowledge on host susceptibility. Climate surfaces obtained from spatial interpolation may contain uncertainty and imprecision (27). Thus, false predictions of European canker risk could result from the errors in the climate surface. Although periods for high host susceptibility would differ by region $(9,12,23,47,48,54)$, it is likely that such knowledge is not readily available for geospatial prediction of the risk of European canker. Use of the $R$ value, as the maximum of $R_{m n}$ over a year, would increase the chance of overprediction of European canker risk. This would minimize frequency of false negative predictions that could result in inadequate control measures and, as a result, unavoidable spread of European canker.

Nevertheless, the rule-based model would predict the risk of European canker accurately when local climate data are available because its parameters were optimized under diverse climate conditions for European canker development. Although the number of calibration sites was small, climate conditions for 12 sets of bimonthly periods at calibration sites were used to optimize the rule-based model. $R_{d}$ values derived from local daily weather data indicated more accurate risk predictions of European canker at Placerville and Geisenheim. Therefore, it is recommended to use local climate data for sites at which the $R$ value was $>0.75$ using the climate estimates in order to verify the actual risk of European canker and to increase the chance of positive detection of high risk areas. Periods for low susceptibility can also be excluded to calculate the $R$ value when local knowledge on host susceptibility becomes available.

Use of the CLIMEX model gave a broadly similar assessment of geographic distribution of European canker risk to the rulebased model although the risk predicted by CLIMEX for some areas contradicted the known distribution of the disease. For example, CLIMEX predicted high risk in eastern South Island of New Zealand, where the disease does not cause a problem. In part, the discrepancies may have resulted from the relatively low spatial resolution of the climate surfaces used. It also appeared that the algorithm on which the CLIMEX model depended could result in errors in classifying the risk of European canker. The risk of European canker could be inflated or deflated for the CLIMEX model when the population GI values incurred errors in representing weekly climate conditions. The EI value is the average of the weekly GI over a year (46). The GI values were high at sites in California and Chile during spring, whereas these
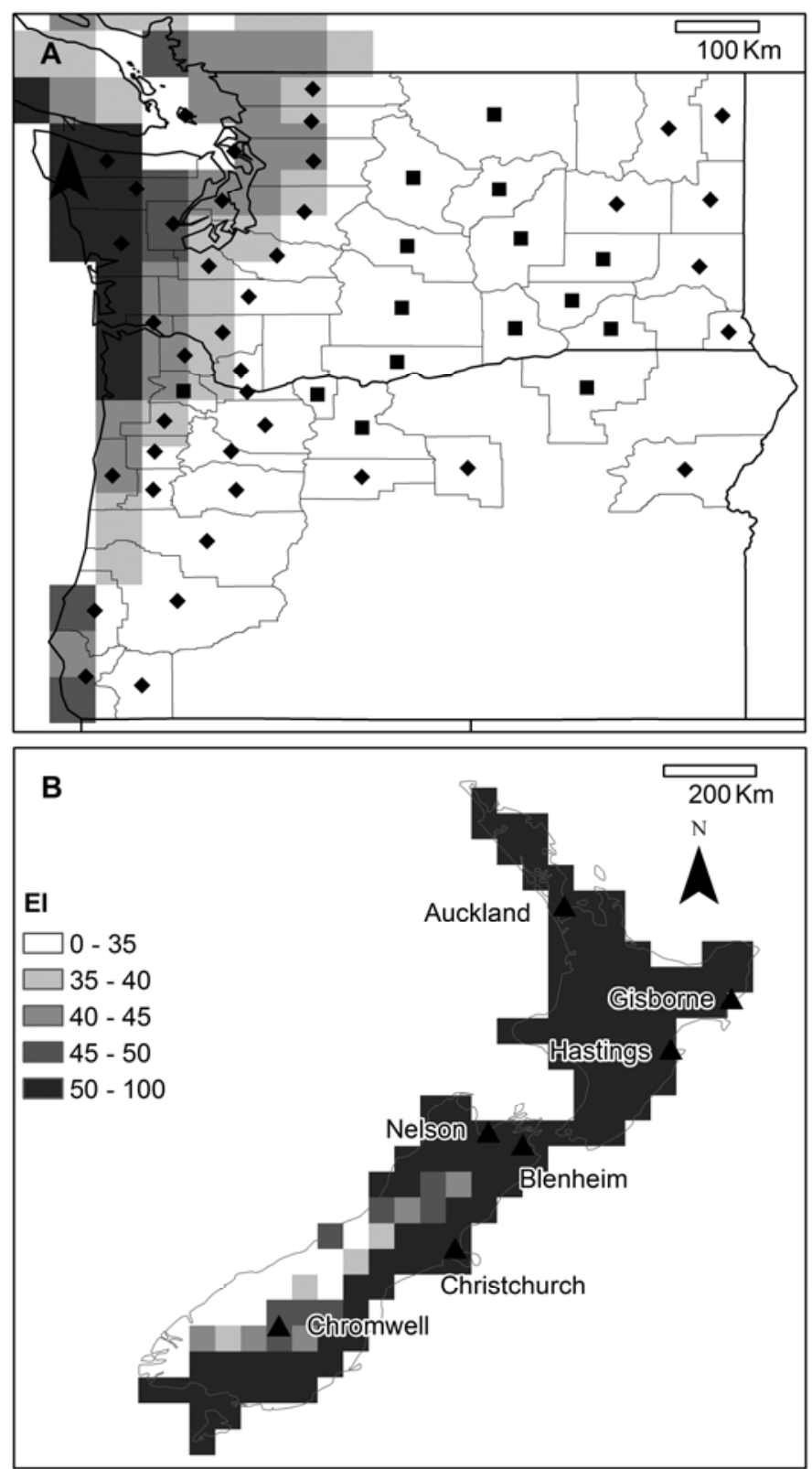

Fig. 8. Maps of risk index (EI) for development of European canker using the CLIMEX model in A, the Pacific Northwest U.S. and B, New Zealand. Areas with EI $>35$ represents nontrivial risk of European canker. Square symbols in A represent counties that have large ( $>200 \mathrm{ha}$ ) apple production area, whereas diamond symbols indicate counties with small apple production area. 
values were relatively low during autumn. However, European canker risk has been reported to be high during leaf fall periods in autumn. As a result, there were sites where the EI failed to represent the risk of European canker reasonably. For example, the EI value was greater at Watsonville than Talca, but European canker has not been reported at Watsonville but has been reported at Talca. These suggested that caution would be needed to interpret the results of the CLIMEX analysis in predicting the risk of European canker unless temporal as well as spatial verification of the CLIMEX prediction could be performed in a region of interest.

Williamson (53) suggested that a drawback of climate matching models is their dependence on correlations between observed geographic distribution of a species and climatic conditions. The current distribution of a species may differ from its potential range due to dispersal barriers $(33,35)$. As a result, the use of climate variables correlated with a species current distribution could lead to incorrect predictions about its potential range (26). A lack of rigorous quantitative data would make it challenging to predict geographical distribution of a species using a correlative approach. Parameters for the CLIMEX model were fitted to 12 sites, whereas those for the rule-based model were determined using only six calibration sites. Even when a satisfactory fit has been found by climate matching, it may be difficult to explain the biological reason for the goodness of fit.

Our results showed that a combination of qualitative and quantitative approaches using fuzzy sets provided a modeling strategy that could overcome weakness associated with correlative climate matching models. The rule-based model described climatic conditions associated with aspects of either the pathogen's biology or disease development that were common across study sites. As a result, the rule-based model was able to detect the risk of European canker when climatic conditions conducive to disease development were observed in a region, even though the region was not included in initial model calibration. In addition, the terms associated with the rule allowed transparent representation of the risk of the disease. These likely contributed to the reason-

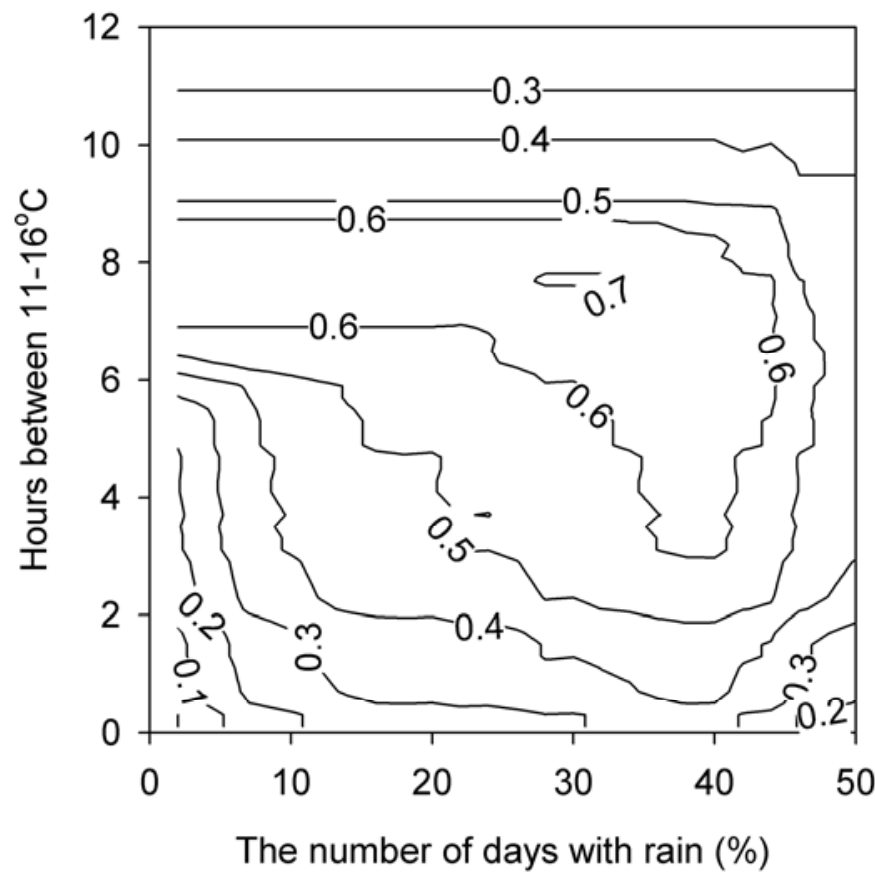

Fig. 9. Contour of the degree of agreement $k$ statistic between the risk level of each 4-week moving window and climatic favorability based on the thresholds of rainfall and temperature variables (3). The $k$ value was at maximum $(0.71)$ with $7.7 \mathrm{~h}$ /day of temperature ranging between 11 and $16^{\circ} \mathrm{C}$ and $28 \%$ of days with rain in a month. able assessment of the climatic risk of European canker. This approach merits further study for predicting the geographic distribution of a wide range of organisms.

\section{APPENDIX}

Climatic thresholds of European canker development. Beresford and Kim (3) performed a moving window analysis using daily weather records for long-term periods, e.g., >10 years, to identify threshold values for rainfall and temperature variables. These threshold values were used to classify climatic suitability for disease development for given periods during which the risk of European canker had been documented. The degree of agreement statistic $k$ between known risk level and classified climatic suitability was maximized when rainfall and temperature thresholds were $28 \%$ of days with rain and $7.7 \mathrm{~h}$ /day with temperature between 11 and $16^{\circ} \mathrm{C}$, respectively (Fig. 9). European canker was a greater problem in areas where the thresholds were exceeded in several months of the year and where they were exceeded by greater amounts.

Calculation of the $\boldsymbol{R}$ values using long-term daily weather data. To compare European canker risk predicted using global climate data and local weather data, daily set of rainfall and temperature was obtained to calculate the $R$ values $\left(R_{d}\right)$. Because the rule-based model was designed to overestimate the risk of European canker, local daily data were obtained at calibration and validation sites with low risk including Placerville $\left(38^{\circ} 43^{\prime} \mathrm{N}\right.$ $\left.120^{\circ} 47^{\prime} \mathrm{W}\right)$, Watsonville $\left(36^{\circ} 54^{\prime} \mathrm{N} 121^{\circ} 45^{\prime} \mathrm{W}\right)$, and Wiesbaden $\left(50^{\circ} 05^{\prime} \mathrm{N} 8^{\circ} 12^{\prime} \mathrm{E}\right)$, which was about $20 \mathrm{~km}$ from Geisenheim. The daily weather data were collected from periods from 1971 to 1991 and from 1971 to 2008 for Placerville and Watsonville, respectively. At Wiesbaden where daily climate data were collected from 1970 to 2009, the amount of rainfall was obtained from the climate surface because precipitation data were not available. The WAVE method was used to calculate the number of hours between 11 and $16^{\circ} \mathrm{C}$ for a $24-\mathrm{h}$ period at these sites. Monthly averages of the number of hours between 11 and $16^{\circ} \mathrm{C}$ were determined in a given year. Monthly averages of rainfall and temperature variables were averaged over the years, for each month. For months when data were missing for more than a week, the month was removed from the analysis.

\section{LITERATURE CITED}

1. Atkinson, J. D. 1971. Diseases of Tree Fruits in New Zealand. Government Printer, Wellington, New Zealand.

2. Berenji, H. R. 1994. The unique strength of fuzzy logic control. IEEE Expert 9:9

3. Beresford, R. M., and Kim, K. S. 2011. Identification of regional climatic conditions favorable for development of European canker of apple. Phytopathology 101:135-146.

4. Booth, T. H., Jovanovic, T., and New, M. 2002. A new world climatic mapping program to assist species selection. For. Ecol. Manag. 163:111-117.

5. Braun, P. G. 1997. Distribution and severity of anthracnose canker and European canker of apple in Kings County, Nova Scotia. Can. J. Plant Pathol. 19:78-82.

6. Busby, J. R. 1991. BIOCLIM-A bioclimate analysis and prediction system. Plant Prot. Q. 6:8-9.

7. Chow, D. H. C., and Levermore, G. J. 2007. New algorithm for generating hourly temperature values using daily maximum, minimum and average values from climate models. Build. Serv. Engineer. Res. Technol. 28:237248.

8. Coakley, S. M., Scherm, H., and Chakraborty, S. 1999. Climate change and plant disease management. Annu. Rev. Phytopathol. 37:399-426.

9. Cooke, L. R. 1999. The influence of fungicide sprays on infection of apple cv. Bramley's seedling by Nectria galligena. Eur. J. Plant Pathol. 105:783-790.

10. Crowdy, S. H. 1952. Observations on apple canker (Nectria galligena). IV. The infection of leaf-scars. Ann. Appl. Biol. 39:569-587.

11. Dietterich, T. G. 2000. An experimental comparison of three methods for constructing ensembles of decision trees: Bagging, boosting, and randomization. Mach. Learn. 40:139-157. 
12. Dubin, H. J., and English, H. 1975. Epidemiology of European apple canker in California. Phytopathology 65:542-550.

13. Goslee, S. C., Peters, D. P. C., and Beck, G. 2006. Spatial prediction of invasion success across heterogeneous landscapes using an individualbased model. Biol. Invasions 8:193-200.

14. Grove, G. G. 1990. Nectria canker. Pages 35-36 in: Compendium of Apple and Pear Diseases. A. L. Jones and H. S. Aldwinckle, eds. The American Phytopathological Society, St. Paul, MN.

15. Heijne, B., de Jong, P. F., Wenneker, M., and Jansonius, P. J. 2005. Slaked lime against European fruit tree canker: Efficacy and introduction into practice. Pages 142-145 in: Researching Sustainable Systems. U. Kopke, U. Niggli, D. Neuhoff, P. Cornish, W. Lockeretz, and H. Willer, eds. Proceedings of the First Scientific Conference of the International Society of Organic Agriculture Research (ISOFAR), Adelaide, South Australia.

16. Heng, Z., Ling, G., Yuxin, Y., and Huairui, S. 2008. Review of the Chinese apple industry. Acta Hort. (ISHS) 772:191-194.

17. Hesler, L. R., and Whetzel, H. H. 1917. Pages 125-130 in: Manual of Fruit Diseases. The Macmillan Company, New York.

18. Huntley, B., Green, R. E., Collingham, Y. C., Hill, J. K., Willis, S. G., Bartlein, P. J., Cramer, W., Hagemeijer, W. J. M., and Thomas, C. J. 2004. The performance of models relating species geographical distributions to climate is independent of trophic level. Ecol. Lett. 7:417-426.

19. Kim, K. S., Yang, X. B., and Tschanz, A. T. 2005. Simulation of apparent infection rate using meteorological variables to predict disease severity of soybean rust. Phytopathology 95:1122-1131.

20. Klir, G. J., and Yuan, B. 1995. Fuzzy Sets and Fuzzy Logic: Theory and Applications. Prentice Hall PTR, Upper Saddle River, NJ.

21. Kriticos, D. J., and Randall, R. P. 2001. A comparison of systems to analyze potential weed distributions. Pages 61-79 in: Weed Risk Assessment. R. H. Groves, F. D. Panetta, and J. G. Virtue, eds. CSIRO Publishing, Collingwood.

22. Kühn, B. F., Andersen, T. T., and Pedersen, H. L. 2003. Evaluation of 14 old unsprayed apple varieties. Biol. Agric. Hort. 20:301-310.

23. Latorre, B. A., Rioja, M. E., Lillo, C., and Muñoz, M. 2002. The effect of temperature and wetness duration on infection and a warning system for European canker (Nectria galligena) of apple in Chile. Crop Prot. 21:285291.

24. Loiselle, B. A., Howell, C. A., Graham, C. H., Goerck, J. M., Brooks, T., Smith, K. G., and Williams, P. H. 2003. Avoiding pitfalls of using species distribution models in conservation planning. Conserv. Biol. 17:15911600 .

25. Lolas, M., and Latorre, B. A. 1996. Importancia y control del cancro europeo del manzano. Rev. Fruticola (Chile) 17:23-27.

26. Mackey, A. P., and Swarbrick, J. T. 1998. Caboma caroliniana A. Gray. Pages 19-36 in: The Biology of Australian Weeds, volume 2. F. D. Panetta, R. H. Groves, and R. C. H. Shepherd, eds. RG and FJ Richardson, Melbourne.

27. Manter, D. K., Reeser, P. W., and Stone, J. K. 2005. A climate-based model for predicting geographic variation in Swiss needle cast severity in the Oregon Coast Range. Phytopathology 95:1256-1265.

28. McCartney, W. O. 1967. An unusual occurrence of eye rot of apple in California due to Nectria galligena. Plant Dis. Rep. 51:278-281.

29. McCracken, A. R., Berrie, A. M., Barbara, D. J., Locke, T., Cooke, L. W., Phelps, K., Swinburne, T. R., Brown, A. E., Ellerker, B., and Langrell, S. R. H. 2003. Relative significance of nursery infections and orchard inoculum in the development and spread of apple canker (Nectria galligena) in young orchards. Plant Pathol. 52:553-566.

30. New, M., Lister, D., Hulme, M., and Makin, I. 2002. A high-resolution data set of surface climate over global land areas. Clim. Res. 21:1-25.

31. Niegel, W. 1988. History, actual advance and future of the equatorian apple growing. Acta Hort. 232:67-73.

32. Özelkan, E. C., and Duckstein, L. 2001. Fuzzy conceptual rainfall-runoff models. J. Hydrol. 253:41-68.
33. Pearson, R. G., and Dawson, T. P. 2003. Predicting the impacts of climate change on the distribution of species: Are bioclimate envelope models useful? Global Ecol. Biogeogr. 12:361-371.

34. Pearson, R. G., Dawson, T. P., Berry, P. M., and Harrison, P. A. 2002. SPECIES: A spatial evaluation of climate impact on the envelope of species. Ecol. Model. 154: 289-300.

35. Peterson, A.T., Soberón, J., and Sánchez-Cordero, V. 1999. Conservatism of ecological niches in evolutionary time. Science 285:1265-1267.

36. Pivonia, S., and Yang, X. B. 2004. Assessment of the potential year-round establishment of soybean rust throughout the world. Plant Dis. 88:523529.

37. Punja, Z. K., and Ormrod, D. J. 1979. New or noteworthy plant diseases in coastal British Columbia 1975-1977. Can. Plant Dis. Surv. 59:22-32

38. Ramsfjell, T. 1950. Et middle mot frukttrekreft. Gartneryrket 3:46-47.

39. Reicosky, D. C., Winkelman, L. J., Baker, J. M., and Baker, D. G. 1989. Accuracy of hourly air temperatures calculated from daily minima and maxima. Agric. For. Meteorol. 46:193-209.

40. Rosso, P. H., and Hansen, E. M. 2003. Predicting Swiss needle cast disease distribution and severity in young Douglas-fir plantations in coastal Oregon. Phytopathology 93:790-798.

41. Scherm, H. 2000. Simulating uncertainty in climate-pest models with fuzzy numbers. Environ. Pollut. 108:373-379.

42. Stockman, A. K., Beamer, D. A., and Bond, J. E. 2006. An evaluation of a GARP model as an approach to predicting the spatial distribution of nonvagile invertebrate species. Diversity Distrib. 12:81-89.

43. Stockwell, D., and Peters, D. 1999. The GARP modelling system: Problems and solutions to automated spatial prediction. Int. J. Geogr. Inf. Sci. 13:143-158

44. Stoy, O. 1940. En mindre bekant sjukdom pa Appeltrad. Fruktodlaren 4:132-134.

45. Sutherst, R. W., and Maywald, G. F. 1985. A computerised system for matching climates in ecology. Agric. Ecosyst. Environ. 13:281-299.

46. Sutherst, R. W., and Maywald, G. F. 1991. Climate modeling and pest establishment. Plant Prot. Q. 6:3-7.

47. Swinburne, T. R. 1971. The seasonal release of spores of Nectria galligena from apple cankers in Northern Ireland. Ann. Appl. Biol. 69:97104.

48. Swinburne, T. R. 1975. European canker of apple (Nectria galligena). Rev. Plant Pathol. 54:787-799.

49. Teng, P. S., and Yang, X. B. 1993. Biological impact and risk assessment in plant pathology. Annu. Rev. Phytopathol. 31:495-521.

50. Uricchio, V. F., Giordano, R., and Lopez, N. 2004. A fuzzy knowledgebased decision support system for ground water pollution risk evaluation. J. Environ. Manag. 73:189-197.

51. Weltzien, H. C. 1972. Geophytopathology. Annu. Rev. Phytopathol. 10:277-298.

52. Wessel, H. 1980. Untersuchungen zum einfluss von klimafaktoren auf die entwicklung des krebses (Nectria galligena) an apfel. Med. Fac. Landbouww. Rijksuniv. Gent. 45:183-190.

53. Williamson, M. 2006. Explaining and predicting the success of invading species at different stages of invasion. Biol. Invasions 8:1561-1568.

54. Wilson, E. E. 1966. Development of European canker in a Californian apple district. Plant Dis. Rep. 50:182-186.

55. Xu, X.-M., and Butt, D. J. 1994. The biology and epidemiology of Nectria galligena and an infection warning system. Norw. J. Agric. Sci. Suppl. No. 17:317-324.

56. Yonow, T., Kriticos, D. J., and Medd, R. W. 2004. The potential geographic range of Pyrenophora semeniperda. Phytopathology 94:805812 .

57. Zagaja, S. W., Millikan, D. F., Kaminski, W., and Myszka, T. 1971. Field resistance to Nectria canker in apple. Plant Dis. Rep. 55:445-447.

58. Zeller, S. M. 1926. European canker of pomaceous fruit trees. Oregon Agric. Exp. Stn. Bull. 222. 